\title{
Leuconostoc kimchii sp. nov., a new species from kimchi
}

\author{
Jeongho Kim, ${ }^{1}$ Jongsik Chun ${ }^{2}$ and Hong-Ui Han ${ }^{1}$
}

\begin{abstract}
1 Department of Biology, Inha University, Inchon 402-751, Republic of Korea

2 Korean Collection for Type Cultures, Korea Research Institute of Bioscience and Biotechnology, Taejon 305-600, Republic of Korea
\end{abstract}

Author for correspondence: Jeongho Kim. Tel: +82 328608691 . Fax: +82 328746737. e-mail: jhokim@inha.ac.kr

\begin{abstract}
A Gram-positive, catalase-negative, facultatively anaerobic, coccus-shaped bacterium, designated $\mathrm{IH}^{2} \mathrm{5}^{\top}$, was isolated from kimchi, a traditional Korean vegetable product. Phylogenetic analysis based on almost complete 16S rDNA sequences placed the isolate in a monophyletic clade corresponding to the genus Leuconostoc. All validly described species in the genus Leuconostoc, with the exception of Leuconostoc fallax, showed high sequence identity of over $97 \%$. The $16 \mathrm{~S}$ rDNA sequence of strain $1 \mathrm{H25} 5^{\top}$ showed the highest homology to those of Leuconostoc gelidum DSM 5578 $(98.9 \%)$ and Leuconostoc citreum KCTC $3526^{\top}$ (98.3\%). However, DNA-DNA hybridization experiments indicated that the organism represents a novel genomic species in the genus, since the previously known leuconostocs share DNA homology with strain $1 \mathrm{IH} 25^{\top}$ of less than $70 \%$. In this work, it is proposed that isolate $1 \mathrm{H}^{2} 5^{\top}$ be classified in the genus Leuconostoc as Leuconostoc kimchii sp. nov. The type strain of Leuconostoc kimchii is IH25' $\left(={\text { KCTC } 2386^{\top}}^{\top}=\right.$ IMSNU $\left.11154^{\top}\right)$.
\end{abstract}

Keywords: Leuconostoc kimchii sp. nov., kimchi, taxonomy, lactic acid bacteria

\section{INTRODUCTION}

The genus Leuconostoc encompasses a phylogenetically coherent group of lactic acid bacteria and currently consists of eight species, namely Leuconostoc mesenteroides, Leuconostoc lactis, Leuconostoc gelidum, Leuconostoc carnosum, Leuconostoc citreum, Leuconostoc pseudomesenteroides, Leuconostoc fallax and Leuconostoc argentinum (Holzapfel \& Schillinger, 1992; Dicks et al., 1993, 1995). L. mesenteroides contains three subspecies, L. mesenteroides subsp. mesenteroides, L. mesenteroides subsp. dextranicum and L. mesenteroides subsp. cremoris (Garvie, 1983). Leuconostocs are Gram-positive, facultatively anaerobic, asporogenous, catalase-negative, spherical organisms containing DNA with relatively low $\mathrm{G}+\mathrm{C}$ content (37-45 mol \%), which produce lactic acid as a main end-product of fermentation and in many cases produce dextran. They thrive in a variety of environments including fermented foods, such as dairy and meat products (Garvie, 1986; Holzapfel \& Schillinger, 1992). Some species have been reported to play an

The GenBank accession numbers for the 16S rDNA sequences of strain $1 \mathrm{H} 25^{\top}$, Leuconostoc citreum KCTC $3526^{\top}$, Leuconostoc argentinum DSM $8581^{\top}$ and Leuconostoc gelidum DSM 5578 ${ }^{\top}$ are AF173986, AF111949, AF175403 and AF175402, respectively. important role in the fermentation of plant materials. For example, L. mesenteroides subsp. mesenteroides initiates the fermentation of sauerkraut and a number of traditional fermented foods in tropical regions (Stamer, 1975; Puspito \& Fleet, 1985; Gashe, 1987).

Kimchi, a traditional Korean food, is a well-known lactic-acid-fermented vegetable product, made of Chinese cabbage, radishes and cucumbers. A typical Korean adult consumes an average of $50-200 \mathrm{~g}$ of kimchi per day. Taxonomically diverse groups of lactic acid bacteria have been found in the fermentation process of kimchi. Some important species responsible for the fermentation of kimchi are leuconostocs such as $L$. mesenteroides, $L$. pseudomesenteroides and $L$. lactis, as well as lactobacilli including Lactobacillus brevis and Lactobacillus plantarum (Lee et al., 1993, 1997). Most taxonomic studies on bacterial isolates from kimchi have been based on limited phenotypic methods, especially biochemical properties such as sugar fermentation patterns. It is clear that a polyphasic approach is needed to pinpoint the accurate taxonomic position of isolates that may play an important role in the fermentation process in kimchi.

In recent work, several Leuconostoc-like bacteria were isolated and identified using a battery of biochemical methods. Among them, a strain was found to have a 
unique biochemical pattern which did not fit the description of any valid species in the genus Leuconostoc. This strain was therefore subjected to further taxonomic study. In this paper, we present the polyphasic characteristics of this isolate, which we name Leuconostoc kimchii sp. nov.

\section{METHODS}

Bacterial strains. A kimchi sample, made from Chinese cabbage, was collected at the initial stage of fermentation, i.e. the first 5 days, at $20^{\circ} \mathrm{C}$. Bacterial strains were isolated using sucrose-agar plates at $20^{\circ} \mathrm{C}$ (Garvie, 1984). The resultant pure cultures were grown in MRS broth (Difco) at $30{ }^{\circ} \mathrm{C}$ for $24 \mathrm{~h}$ and stored in $10 \%(\mathrm{v} / \mathrm{v})$ dimethyl sulfoxide at $-70{ }^{\circ} \mathrm{C}$. An isolate, designated $\mathrm{IH} 25^{\mathrm{T}}$, was shown to have a distinctive biochemical pattern and was chosen for further studies. The type strains used in this study are L. argentinum DSM 8581 ${ }^{\mathrm{T}}$, L. carnosum DSM 5576 ${ }^{\mathrm{T}}$, L. citreum KCTC $3526^{\mathrm{T}}$, L. fallax DSM 20189 ${ }^{\mathrm{T}}$, L. gelidum DSM 5578 , L. mesenteroides subsp. mesenteroides KCTC $3505^{\mathrm{T}}$, L. lactis KCTC $3528^{\mathrm{T}}$ and L. pseudomesenteroides DSM 20193 ${ }^{\mathrm{T}}$. All strains except L. gelidum were cultivated at $30^{\circ} \mathrm{C}$, unless otherwise stated.

Biochemical and physiological tests. The strains were characterized biochemically using the API CH50 strip and API CHL medium systems according to the manufacturer's instructions (API bioMérieux). All test preparations were incubated for $48 \mathrm{~h}$ before reading colour changes. Determination of the optical isomer of lactic acid by using lactate dehydrogenases was carried out according to the manufacturer's instructions (TC D-/L-lactic acid, Boehringer Mannheim) (Okada et al., 1978). Arginine dihydrolase activity was tested by using $1 \%$ L-arginine monohydrochloride (Smibert \& Krieg, 1994).

Cellular fatty acid analysis. Fatty acid methyl esters were prepared from biomass that was scraped from MRS agar incubated for $24 \mathrm{~h}$ at $30^{\circ} \mathrm{C}$. The composition of whole-cell fatty acids was determined using the MIDI system (Hewlett Packard; Sasser, 1990).

16S rDNA sequencing. Chromosomal DNA was isolated by a modification of the method of Varmanen et al. (1998). Mid-exponential-phase cells $\left(\mathrm{OD}_{600}=0.4\right)$ in $3 \mathrm{ml}$ MRS broth containing $1 \%(\mathrm{w} / \mathrm{v})$ glycine were pelleted and resuspended in $380 \mu 16.7 \%$ sucrose solution (in TE buffer; $50 \mathrm{mM}$ Tris/ $\mathrm{HCl}, 1 \mathrm{mM}$ EDTA, pH 8.0). One hundred microlitres lysozyme $\left(50 \mathrm{mg} \mathrm{ml}^{-1}\right)$ and $5 \mu \mathrm{l}$ RNase A $\left(10 \mathrm{mg} \mathrm{ml}^{-1}\right)$ were added and the cells were incubated at $37^{\circ} \mathrm{C}$ for $1 \mathrm{~h}$. Cells were lysed by adding $30 \mu 120 \%$ SDS (in TE buffer). Cell lysates were incubated by adding $20 \mu \mathrm{l}$ proteinase $\mathrm{K}\left(17 \mathrm{mg} \mathrm{ml}^{-1}\right)$ at $50{ }^{\circ} \mathrm{C}$ for $1 \mathrm{~h}$. Cell lysates were diluted fourfold with buffer $(10 \mathrm{mM}$ Tris $/ \mathrm{HCl} \mathrm{pH} 8 \cdot 0,1 \mathrm{mM}$ EDTA) and were then subjected to phenol extraction and ethanol precipitation. PCR amplification of the $16 \mathrm{~S}$ rDNA was performed in a $100 \mu \mathrm{l}$ reaction containing $2.5 \mathrm{U}$ Taq polymerase by using the following program: 30 cycles consisting of denaturation at $94{ }^{\circ} \mathrm{C}$ for $1 \mathrm{~min}$, annealing at $55^{\circ} \mathrm{C}$ for $1 \mathrm{~min}$ and extension at $72{ }^{\circ} \mathrm{C}$ for $2 \mathrm{~min}$ and an additional extension step at $72{ }^{\circ} \mathrm{C}$ for $10 \mathrm{~min}$. The primers used were 5'-GAGTTTGATCCTGGCTCAG-3' (Escherichia coli numbering system, positions 9-27) and 5'-AGAAAGGAGGTGATCCAGCC-3' (positions 1525-1544) (Brosius et al., 1978; Suzuki \& Yamasato, 1994). PCR products were cloned into pGEM vector (Promega) and sequenced by using a dideoxy sequencing kit (Sequenase version 2.0, USB).
Phylogenetic analysis. The resultant $16 \mathrm{~S}$ rDNA sequence of strain $\mathrm{IH} 25^{\mathrm{T}}$ was aligned manually against representative sequences of lactic acid bacteria obtained from GenBank using information on secondary structure. Unrooted evolutionary trees were inferred by using three treeing algorithms, namely, the Fitch-Margoliash (Fitch \& Margoliash, 1967), maximum-parsimony (Fitch, 1972) and neighbourjoining (Saitou \& Nei, 1987) methods. The distance model of Jukes \& Cantor (1969) was used to generate an evolutionary distance matrix. The topologies of the resulting trees were evaluated by bootstrap analyses (Felsenstein, 1985) of the neighbour-joining method based on 1000 resamplings. All phylogenetic analyses were carried out using the PHYLIP package (Felsenstein, 1993).

DNA-DNA relatedness studies. DNA relatedness among strains was determined in duplicate experiments by using the membrane filter technique modified after Chun et al. (1998). Genomic DNA (200 ng) was denatured by using the alkaline method and immobilized on nylon membrane (Hybond- $\mathrm{N}^{+}$; Amersham) by applying a low vacuum. DNA preparations were labelled with the ECL direct nucleic acid labelling and detection kit (RPN 3000; Amersham). One hundred nanograms of the denatured DNA samples was labelled with glutaraldehyde according to the manufacturer's protocol. The membranes were prehybridized in hybridization solution at $42{ }^{\circ} \mathrm{C}$ for $2 \mathrm{~h}$. Hybridization was carried out in $10 \mathrm{ml}$ hybridization solution containing labelled DNA $\left(10 \mathrm{ng} \mathrm{ml}^{-1}\right)$ at $42{ }^{\circ} \mathrm{C}$ for $2 \mathrm{~h}$. After hybridization, the nylon filters were washed twice in primary wash solution $(0 \cdot 4 \%$ SDS, $0 \cdot 1 \times \mathrm{SSC}$ ) at $42{ }^{\circ} \mathrm{C}$ and subsequently washed twice with secondary wash solution $(2 \times \mathrm{SSC})$. Detection reagents were added to the membrane blots for $1 \mathrm{~min}$ at room temperature and were then drained off. Membrane blots wrapped in SaranWrap were exposed to autoradiography film (Hyperfilm-ECL; Amersham) for 0.5-2 min. The signal intensities were determined by using an image analyser (Pharmacia). The signal produced by self-hybridization was taken as $100 \%$ and percentage homology values were calculated for the duplicate samples.

Determination of DNA base composition. DNA was prepared according to Chun \& Goodfellow (1995). The G+C contents of the resultant preparations were determined by the thermal denaturation method (Mandel \& Marmur, 1968).

\section{RESULTS AND DISCUSSION}

Isolate IH $25^{\mathrm{T}}$ showed phenotypic characteristics typical of leuconostocs, i.e. a Gram-positive, non-sporeforming, coccus-shaped, facultatively anaerobic, catalase-negative organism that usually occurs as single cells or in pairs. The $\mathrm{G}+\mathrm{C}$ content of the organism, $37 \mathrm{~mol} \%$, was within the observed range for the genus Leuconostoc, i.e. $37-45 \mathrm{~mol} \%$ (Garvie, 1983). As is typical of leuconostocs, more than $95 \%$ of the lactate produced by strain $\mathrm{IH} 25^{\mathrm{T}}$ was the $\mathrm{D}-(-)$ isomer and the strain did not hydrolyse arginine. The organism contained major amounts of straight-chain saturated, monounsaturated and cyclopropane-ring acids: $\mathrm{C}_{16: 0}$ $(35 \%), \mathrm{C}_{19 \text {-cyclo }}(29 \%), \mathrm{C}_{18: 1}(16 \%), \mathrm{C}_{16: 1}(10 \%)$ and $\mathrm{C}_{14: 0}(7 \%)$. The presence of large amounts of the $\mathrm{C}_{19}$ cyclopropane-ring acid and its precursor $\left(\mathrm{C}_{18: 1}\right)$ was also reported in other leuconostocs (Shaw \& Harding, 1989). Our isolate has a profile most similar to those of L. gelidum and L. carnosum. However, strain $\mathrm{IH} 25^{\mathrm{T}}$ 


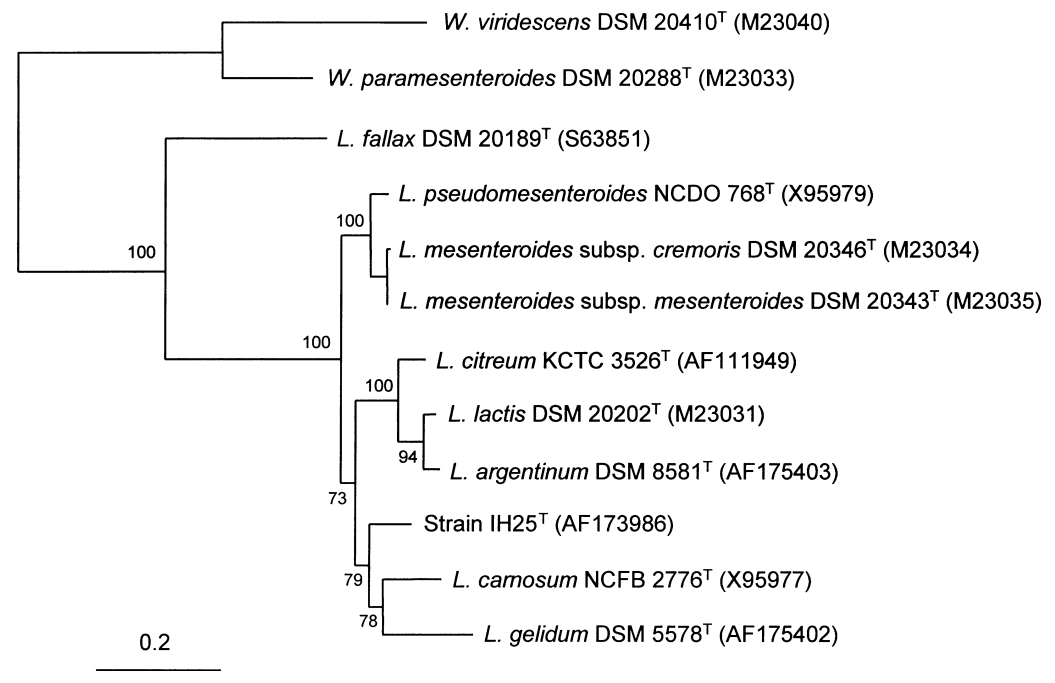

Fig. 1. Unrooted neighbour-joining tree based on nearly complete $16 \mathrm{~S}$ rDNA sequences showing relationships between strain $\mathrm{IH}_{25} 5^{\top}$ and members of the genus Leuconostoc. Numbers at the nodes indicate levels of bootstrap support based on neighbour-joining analyses of 1000 resampled datasets. The scale bar indicates 0.2 nucleotide substitutions per nucleotide position. W., Weissella.

Table 1. Mean levels of DNA relatedness (\%) of strain $\mathrm{IH}_{2} 5^{\top}$ to Leuconostoc strains

\begin{tabular}{|c|c|c|c|}
\hline \multirow[t]{2}{*}{ Strain } & \multicolumn{3}{|c|}{ Labelled strain } \\
\hline & $\mathrm{IH}^{2} 5^{\mathrm{T}}$ & DSM 5578 & DSM 20193 \\
\hline Strain $\mathrm{IH} 25^{\mathrm{T}}$ & 100 & 40 & 2 \\
\hline L. argentinum DSM $8581^{\mathrm{T}}$ & 7 & 10 & 4 \\
\hline L. carnosum DSM $5576^{\mathrm{T}}$ & 7 & 40 & 2 \\
\hline L. citreum KCTC $3526^{\mathrm{T}}$ & 2 & 20 & 2 \\
\hline L. fallax DSM 20189 & 1 & ND & 1 \\
\hline L. gelidum DSM $5578^{\mathrm{T}}$ & 17 & 100 & 2 \\
\hline L. lactis $\mathrm{KCTC} 3528^{\mathrm{T}}$ & 2 & 8 & 2 \\
\hline L. mesenteroides subsp. cremoris DSM $20346^{\mathrm{T}}$ & 24 & ND & 5 \\
\hline L. mesenteroides subsp. dextranicum DSM 20484 & 2 & ND & 3 \\
\hline L. mesenteroides subsp. mesenteroides $\mathrm{KCTC} 3505^{\mathrm{T}}$ & 2 & 20 & 2 \\
\hline L. pseudomesenteroides DSM 20193 ${ }^{\mathrm{T}}$ & 2 & 15 & 100 \\
\hline Weissella paramesenteroides DSM $20288^{\mathrm{T}}$ & 1 & 8 & 2 \\
\hline
\end{tabular}

ND, Not determined.

differed from L. gelidum strains in that the former contained significantly less $\mathrm{C}_{16: 1}(10 \%)$ than did the latter (19-20.5\%). Similarly, our isolate and L. carnosum strains exhibited substantial differences in the relative amounts of $\mathrm{C}_{17 \text {-cyclo }}$ and $\mathrm{C}_{19 \text {-cyclo. }}$. It is evident from the fatty acid analysis that our isolate belongs to the genus Leuconostoc and has a distinctive profile that can be used to differentiate it from other leuconostocs. Such an identification at the genus level was confirmed by $16 \mathrm{~S}$ rDNA analysis, for which almost-complete $16 \mathrm{~S}$ rDNA sequences were determined for strain IH $25^{\mathrm{T}}, L$. argentinum DSM $8581^{\mathrm{T}}$, L. citreum KCTC $3526^{\mathrm{T}}$ and L. gelidum DSM 5578 ${ }^{\mathrm{T}}$ (positions $28-1524,1505 \mathrm{nt}$ ).
The unrooted tree based on the neighbour-joining method clearly placed strain $\mathrm{IH} 25^{\mathrm{T}}$ in a clade corresponding to the genus Leuconostoc (Fig. 1). An identical tree topology was recovered using the FitchMargoliash and maximum-parsimony methods. The isolate formed a monophyletic clade with the type strains of $L$. carnosum and $L$. gelidum that was supported by a relatively high bootstrap value of $79 \%$. The test strain showed a high level of $16 \mathrm{~S}$ rDNA similarity to Leuconostoc species, ranging from $92.5 \%$ (L. fallax DSM 20189 ${ }^{\mathrm{T}}$ ) to $98.9 \%$ (L. gelidum DSM $\left.5578^{\mathrm{T}}\right)$. Intermediate values were $98 \cdot 3 \%(L$. citreum KCTC $3526^{\mathrm{T}}$ ), 98.3\% (L. carnosum NCFB $2776^{\mathrm{T}}$ ), 
Table 2. Phenotypic characteristics of Leuconostoc species

Taxa are labelled as: 1 , strain $\mathrm{IH} 25^{\mathrm{T}} ; 2$, L. argentinum; $3, L$. carnosum; 4, L. citreum KCTC $3526^{\mathrm{T}}$; 5, L. gelidum DSM $5578^{\mathrm{T}} ;$ 6, L. lactis KCTC $3528^{\mathrm{T}}$; 7, L. mesenteroides subsp. mesenteroides; 8, L. pseudomesenteroides. Data for taxa 2, 3, 7 and 8 were taken from previous studies (Dicks et al., 1993; Shaw \& Harding, 1989; Farrow et al., 1989; Garvie, 1986). Characteristics are scored as: + , more than $90 \%$ of strains positive; - , more than $90 \%$ of strains negative; $v$, variable; D, delayed reaction. ND, Not determined.

\begin{tabular}{|lccccccccc|}
\hline Characteristic & $\mathbf{1}$ & $\mathbf{2}$ & $\mathbf{3}$ & $\mathbf{4}$ & $\mathbf{5}$ & $\mathbf{6}$ & $\mathbf{7}$ & $\mathbf{8}$ \\
\hline Acid produced from: & & & & & & & & & \\
L-Arabinose & - & $\mathrm{V}$ & - & + & + & + & + & $\mathrm{V}$ \\
Cellobiose & + & $\mathrm{V}$ & - & + & + & - & $\mathrm{D}$ & $\mathrm{V}$ \\
Galactose & + & + & - & + & - & + & + & + \\
Gluconate & + & - & + & + & + & - & $\mathrm{ND}$ & $\mathrm{V}$ \\
Lactose & + & + & - & - & - & + & $\mathrm{D}$ & $\mathrm{V}$ \\
Mannitol & + & $\mathrm{V}$ & + & + & + & - & $\mathrm{D}$ & - \\
Melibiose & - & + & $\mathrm{V}$ & - & + & - & $\mathrm{D}$ & + \\
Raffinose & - & + & - & - & + & - & $\mathrm{D}$ & + \\
Ribose & + & - & $\mathrm{V}$ & - & + & - & + & + \\
Salicin & + & - & - & + & + & - & $\mathrm{D}$ & $\mathrm{V}$ \\
Trehalose & + & $\mathrm{V}$ & + & + & + & - & + & + \\
D-Xylose & - & $\mathrm{V}$ & - & - & + & - & $\mathrm{D}$ & + \\
\hline
\end{tabular}

$98 \cdot 2 \%$ (L. pseudomesenteroides NCDO $768^{\mathrm{T}}$ ), 97.7\% (L. mesenteroides subsp. mesenteroides DSM 20343 ${ }^{\mathrm{T}}$ ), $97.6 \%\left(\right.$ L. argentinum DSM $\left.8581^{\mathrm{T}}\right)$ and $97.5 \%(L$. lactis DSM 20202 ${ }^{\mathrm{T}}$ ). All leuconostocs except L. fallax showed at least $97 \%$ similarity to the kimchi isolate, the level proposed as the borderline for defining bacterial genomic species on the basis of $16 \mathrm{~S}$ rDNA comparison (Stackebrandt \& Goebel, 1994). The genealogical relatedness of our isolate to other leuconostocs was elucidated further using DNA-DNA pairing experiments (Table 1). Strain $\mathrm{IH} 25^{\mathrm{T}}$ showed similarity of $1-24 \%$ to the type strains of the genus Leuconostoc when DNA from strain $\mathrm{IH} 25^{\mathrm{T}}$ was labelled. Similarly, when other strains were labelled, the highest binding, $40 \%$, was recorded for L. gelidum DSM $5578^{\mathrm{T}}$. In any case, the homology values were less than $70 \%$, which has been proposed to define genomic species (Wayne et al., 1987). It is evident from $16 \mathrm{~S}$ rDNA and DNA-DNA hybridization data that strain $\mathrm{IH} 25^{\mathrm{T}}$ represents an independent genomic species that can be separated genetically from all validly described leuconostocs. The combination of tests for acid production from sugars readily distinguishes strain $\mathrm{IH} 25^{\mathrm{T}}$ from related leuconostocs (Table 2). All known strains of L. gelidum utilize arabinose, melibiose, raffinose and D-xylose but not galactose or lactose (Shaw \& Harding, 1989). However, IH $25^{\mathrm{T}}$ did not produce acid from arabinose, melibiose, raffinose or D-xylose but did produce acid from galactose and lactose. $\mathrm{IH} 25^{\mathrm{T}}$ was also distinguished from strains of
L. citreum in its usage of lactose and ribose (Table 2; Farrow et al., 1989).

Leuconostocs have long been known to be residents of the normal flora of vegetable and fermented-vegetable products (Stiles, 1996). The predominant Leuconostoc species in kimchi is thought to be L. mesenteroides, although several other leuconostocs such as $L$. pseudomesenteroides and L. lactis are also recovered in kimchi on a regular basis. Our recent work has shown that $L$. citreum was one of the predominant species during kimchi fermentation at $20^{\circ} \mathrm{C}$ and that L. gelidum was a dominant species at lower temperatures, for example $10{ }^{\circ} \mathrm{C}$ (J. Kim and others, unpublished results). The recognition of a new leuconostoc, i.e. strain $\mathrm{IH} 25^{\mathrm{T}}$, in kimchi fermentation made from Chinese cabbage strongly implies that the microbial diversity in kimchi fermentation has been rather underestimated. A polyphasic approach is essential to characterize further the microbial diversity of kimchi fermentation.

On the basis of molecular, chemical and phenotypic data, we propose that kimchi isolate $\mathrm{IH} 25^{\mathrm{T}}$ be classified in the genus Leuconostoc as Leuconostoc kimchii sp. nov.

\section{Description of Leuconostoc kimchii sp. nov.}

Leuconostoc kimchii (kim'chi.i. M.L. gen. kimchii of kimchi, a traditional Korean food made by fermentation of Chinese cabbage).

Cells are spherical but similar to coccobacilli and occur singly or in pairs. Gram-positive, non-motile and nonspore-forming cells are catalase-negative and facultatively anaerobic. Grows at 15 and $37^{\circ} \mathrm{C}$ but not at $45^{\circ} \mathrm{C}$. Grows in the presence of $7 \% \mathrm{NaCl}$ but not $10 \%$ $\mathrm{NaCl}$. Produces dextran from sucrose and gas from glucose. More than $95 \%$ of the lactate produced is as the D- $(-)$ isomer. Arginine is not hydrolysed. Acid is produced from amygdalin, arabinose, cellobiose, galactose, gluconate, lactose, mannitol, ribose, salicin, trehalose, turanose, fructose, maltose, mannose and sucrose, but not from melezitose, sorbitol, starch, rhamnose, inulin, melibiose, raffinose or xylose. Major cellular fatty acids are straight-chain saturated, monounsaturated and cyclopropane-ring acids.

The $\mathrm{G}+\mathrm{C}$ content of the DNA of the type strain is $37 \mathrm{~mol} \%$. The type and only strain, IH $25^{\mathrm{T}}$, has been deposited in the Korean Collection for Type Cultures as KCTC $2386^{\mathrm{T}}$ and the culture collection of the Institute of Microbiology, Seoul National University as IMSNU $11154^{\mathrm{T}}$.

\section{ACKNOWLEDGEMENTS}

This work was supported by the Inha University and the Korea Research Foundation in the 21 st Century. We would like to thank Professor H. G. Trüper for help with nomenclature. We are also grateful to I. Choi, M. Rhee, B. Kim, S. Park, J. Jung and H. Lee for their technical assistance. 


\section{REFERENCES}

Brosius, J., Palmer, M. L., Kennedy, P. J. \& Noller, H. F. (1978). Complete nucleotide sequence of a $16 \mathrm{~S}$ ribosomal RNA gene from Escherichia coli, Proc Natl Acad Sci U S A 75, 4801-4805.

Chun, J. \& Goodfellow, M. (1995). A phylogenetic analysis of the genus Nocardia with 16S rRNA gene sequences, Int $J$ Syst Bacteriol 45, 240-245.

Chun, J., Seong, C.-N., Bae, K. S., Lee, K.-J., Kang, S.-O., Goodfellow, M. \& Hah, Y. C. (1998). Nocardia flavorosea sp. nov, Int J Syst Bacteriol 48, 901-905.

Dicks, L. M. T., Fantuzzi, L., Gonzalez, F. C., Du Toit, M. \& Dellaglio, F. (1993). Leuconostoc argentinum sp. nov., isolated from Argentine raw milk, Int J Syst Bacteriol 43, 347-351.

Dicks, L. M. T., Dellaglio, F. \& Collins, M. D. (1995). Proposal to reclassify Leuconostoc oenos as Oenococcus oeni [corrig.] gen. nov., comb. nov, Int J Syst Bacteriol 45, 395-397.

Farrow, J. A. E., Facklam, R. R. \& Collins, M. D. (1989). Nucleic acid homologies of some vancomycin-resistant leuconostocs and description of Leuconostoc citreum sp. nov. and Leuconostoc pseudomesenteroides sp. nov, Int J Syst Bacteriol 39, 279-283.

Felsenstein, J. (1985). Confidence limits on phylogenies: an approach using the bootstrap, Evolution 39, 783-791.

Felsenstein, J. (1993). PHYLIP (phylogenetic inference package) version 3.5c. Seattle: University of Washington.

Fitch, W. M. (1972). Toward defining the course of evolution: minimum change for a specific tree topology, Syst Zool 20, 406-416.

Fitch, W. M. \& Margoliash, E. (1967). Construction of phylogenetic trees, Science 155, 279-284.

Garvie, E. I. (1983). Leuconostoc mesenteroides subsp. cremoris (Knudsen and Sørensen) comb. nov. and Leuconostoc mesenteroides subsp. dextranicum (Beijerinck) comb. nov, Int J Syst Bacteriol 33, 118-119.

Garvie, E. I. (1984). Separation of species of the genus Leuconostoc and differentiation of the leuconostocs from other lactic acid bacteria, Methods Microbiol 16, 147-178.

Garvie, E. I. (1986). Genus Leuconostoc. In Bergey's Manual of Systematic Bacteriology, vol. 2, pp. 1071-1075. Edited by P. H. A. Sneath, N. S. Mair, M. E. Sharpe \& J. G. Holt. Baltimore: Williams \& Wilkins.

Gashe, B. A. (1987). Kocho fermentation, J Appl Bacteriol 62, 473-478.

Holzapfel, W. H. \& Schillinger, U. (1992). The genus Leuconostoc. In The Prokaryotes, pp. 1508-1534. Edited by A. Balows, H. G. Trüper, M. Dworkin, W. Harder \& K. H. Schleifer. New York: Springer.

Jukes, T. H. \& Cantor, C. R. (1969). Evolution of protein mol- ecules. In Mammalian Protein Metabolism, pp. 21-132. Edited by H. N. Munro. New York: Academic Press.

Lee, H. J., Baek, J., Yang, M., Han, H., Ko, Y. \& Kim, H. (1993). Characteristics of lactic acid bacterial community during kimchi fermentation by temperature downshift, Kor J Microbiol 31, 346-353.

Lee, J., Chun, C., Jung, M., Ahn, J., Park, Y. \& Mheen, T. (1997). Classification of isolates originating from kimchi using carbonsource utilization patterns, J Microbiol Biotechnol 7, 68-74.

Mandel, M. \& Marmur, J. (1968). Use of ultraviolet absorbance temperature profile for determining the guanine plus cytosine content of DNA, Methods Enzymol 12B, 195-206.

Okada, S., Toyada, T. \& Kozaki, M. (1978). An easy method for the determination of the optical types of lactic acid produced by lactic acid bacteria, Agric Biol Chem 42, 1781-1783.

Puspito, H. \& Fleet, G. H. (1985). Microbiology of Sayur-Asin fermentation, Appl Microbiol Biotechnol 22, 442-445.

Saitou, N. \& Nei, M. (1987). The neighbor-joining method: a new method for reconstructing phylogenetic trees, Mol Biol Evol 4, 406-425.

Sasser, M. (1990). Identification of Bacteria by Gas Chromatography of Cellular Fatty Acids. Technical Note 101. Newark, DE: Microbial ID Inc.

Shaw, B. G. \& Harding, C. D. (1989). Leuconostoc gelidum sp. nov. and Leuconostoc carnosum sp. nov. from chill-stored meats, Int J Syst Bacteriol 39, 217-223.

Smibert, R. M. \& Krieg, N. R. (1994). Phenotypic characterization. In Methods for General and Molecular Bacteriology, pp. 607654. Edited by P. Gerhardt, R. Murray, W. A. Wood \& N. R. Krieg. Washington, DC: American Society for Microbiology.

Stackebrandt, E. \& Goebel, B. M. (1994). Taxonomic note: a place for DNA-DNA reassociation and $16 \mathrm{~S}$ rRNA sequence analysis in the present species definition in bacteriology, Int $J$ Syst Bacteriol 44, 846-849.

Stamer, J. R. (1975). Recent developments in the fermentation of sauerkraut. In Lactic Acid Bacteria in Beverages and Food, pp. 267-280. Edited by J. G. Carr, C. V. Cutting \& G. C. Whiting. London: Academic Press.

Stiles, M. E. (1996). Biopreservation by lactic acid bacteria, Antonie Leeuwenhoek 70, 331-345.

Suzuki, T. \& Yamasato, K. (1994). Phylogeny of spore-forming lactic acid bacteria based on $16 \mathrm{~S}$ rRNA gene sequences, FEMS Microbiol Lett 115, 13-18.

Varmanen, P., Rantanen, T., Ralva, A. \& Tynkkynen, S. (1998). Cloning and characterization of a prolinase gene (perR) from Lactobacillus rhamnosus, Appl Environ Microbiol 64, 1831-1836.

Wayne, L. G., Brenner, D. J., Colwell, R. R. \& 9 other authors (1987). Report of the ad hoc committee on reconciliation of approaches to bacterial systematics. Int J Syst Bacteriol 37 463-464. 